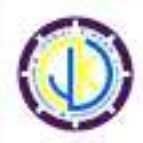

e-ISSN: $2580-6947$

p-ISSN: 2354-7278

http://ojs.umrah.ac.id/index.php/kiprah/index

\title{
FOLKLOR KEPERCAYAAN RAKYAT MASYARAKAT MELAYU DI KABUPATEN BINTAN
}

\author{
Tessa Dwi Leoni*, Wahyu Indrayatti
}

Universitas Maritim Raja Ali Haji, Kota Tanjungpinang, Kepulauan Riau 29115, Indonesia

\begin{abstract}
Abstrak
Penelitian ini bertujuan untuk mendeskripsikan folklor kepercayaan rakyat pada masyarakat Melayu di Kabupaten Bintan. Metode yang digunakan dalam penelitian ini adalah metode analisis deskriptif. Data dalam penelitian ini ialah tradisi lisan masyarakat Melayu di Kabupaten Bintan. Data bersumber dari masyarakat asli Melayu Kabupaten Bintan. Penelitian ini dirumuskan dengan teori folklor dan didukung oleh teori sastra Indonesia. Hasil penelitian ini berupa: (1) kepercayaan rakyat masyarakat berhubungan dengan lingkaran hidup manusia; (2) kepercayaan rakyat masyarakat mengenai alam gaib; (3) kepercayaan rakyat masyarakat mengenai terciptanya alam semesta dan dunia, dan (4) fungsi kepercayaan rakyat dalam kehidupan masyarakat.
\end{abstract}

Kata Kunci: folklor; kepercayaan rakyat; Kabupaten Bintan

\begin{abstract}
This is descreptive research aimed to describe beliefs in the Malay society in Bintan. The data of the study are oral informations derived from informen who are people indigenous Malay Bintan. The data were analyzed refering to folklore and Indonesian literary theory. The results of this study are: (1) belief of Malay people in Bintan related to the circle of human life; (2) belief of supernatural; (3) Beliefs of universe creation; and (4) the function of belief in the Society.
\end{abstract}

Keywords: folklore, belief, Malay, Bintan

\section{PENDAHULUAN}

Sastra lisan merupakan salah satu basis dari siklus perkembangan kesusasteraan Indonesia. Kebudayaan tersebut harus didokumentasi dengan baik agar tidak punah oleh perkembangan zaman dan tergerus budaya asing yang sudah mulai diikuti generasi muda Indonesia, termasuk wilayah Kabupaten Bintan yang merupakan kabupaten yang sedang berkembang, dan secara geografis berbatasan langsung dengan negara tetangga Malaysia dan Singapura. Selain itu, bahwa perkembangan teknologi khususnya komunikasi sudah mengalihkan perhatian generasi muda, sehingga seakan kebudayaan hanya menjadi milik para orang tua saja.

Pada zaman dahulu, masyarakat Melayu sangat terkenal dengan tradisi lisannya.
Bahkan budaya menulis bisa dikatakan jauh dari kebiasaan orang Melayu pada saat itu. Hanya beberapa orang sastrawan Melayu yang menuangkan karyanya dalam tulisan. Namun, pada saat ini, di wilayah Kabupaten Bintan, selain rendahnya tranliterasi dari lisan ke tulisan, pewarisan kebudayaan secara lisan dari generasi tua kepada generasi muda pun sangat jauh dari harapan. Kebanyakan generasi tua saat ini lebih disibukkan dengan pekerjaan, sementara itu, anak-anak lebih banyak waktunya untuk sekolah ketimbang berkumpul dengan keluarga di rumah. Kondisi ini dikhawatirkan akan sangat berdampak pada miskinnya pengetahuan generasi muda terhadap kekayaan sastra lisan yang sedari dulu pernah berjaya di negeri kelahiran mereka sendiri. 
Artikel ini mengkaji kepercayaan rakyat masyarakat Melayu di Kabupaten Bintan yang berkaitan dengan sastra lisan mengenai lingkar kehidupan, mengenai alam gaib, dan mengenai proses terciptanya alam semesta dan dunia. Penggolongan tersebut, mengacu pada penggolongan teori oleh Wayland D. Hand (dalam James Danandjaya: 1991). Sebagian besar masyarakat Bintan, masih memelihara kepercayaan yang diwariskan secara turun temurun oleh leluhur mereka. Kepercayaankepercayaan tersebut, sangat menarik untuk dijadikan pembelajaran, terlebih sebagian besar daerah Kepulauan Riau merupakan hamparan lautan yang luas. Masyarakat sudah terbiasa mengambil contoh pelajaran dari tata cara mereka bereaksi dengan alam sekitar. Alam dijadikan sebagai pembelajaran terbaik oleh masyarakat. Nilai-nilai dan pembelajaran dari alam kemudian disampaikan oleh para leluhur kepada generasi muda dengan media sastra lisan.

\section{METODE}

Metode penelitian ini adalah kualitatif deskriptif dengan menggunakan metode analisis isi (content analysis) untuk menggali isi, pesan, dan nilai-nilai yang terkandung pada objek penelitian. Menurut Sugiyono (2005:1) penelitian kualitatif adalah jenis penelitian yang digunakan untuk meneliti pada kondisi objek alamiah, peneliti merupakan instrumen kunci, hasil penelitian lebih menekankan makna daripada generalisasi. Data penelitian ini adalah kepercayaan masyarakat Melayu di Kabupaten Bintan. Data tersebut dikumpulkan dari objek penelitian yaitu folklor sebagian lisan masyarakat Melayu di Kabupaten Bintan. Objek penelitian ini dikumpulkan melalui pengamatan (dengan perekaman dan pencatatan) dan wawancara. Data berupa kepercayaan rakyat didapatkan dari informan dengan kriteria berikut: (1) berenkulturasi penuh, (2) terlibat langsung, (3) memunyai waktu yang cukup, (4) nonanalitis, (5) produktif.

\section{HASIL DAN PEMBAHASAN}

Pengamatan dan wawancara telah dilakukan oleh peneliti dengan melibatkan beberapa informan yang merupakan penduduk asli Kabupaten Bintan pada 10 kecamatan dari wilayah daratan hingga pesisir, yaitu ; Bintan Pesisir, Bintan Timur, Bintan Utara, Gunung Kijang, Mantang, Seri Kuala Lobam, Tambelan, Teluk Bintan, Teluk sebong, dan Toapaya. Meskipun jumlah penduduk di kabupaten Bintan masih sedikit, dan masih didominasi hutan, namun, keterhubungan penduduk dari kecamatan yang satu dengan kecamatan yang lainnya tergolong baik. Hal tersebut karena pemerintah setempat sudah berangsur-angsur memperbaiki infrastruktur jalan utama yang menghubungkan satu kecamatan dengan kecamatan lainnya.

Menurut Roger Tol dan Pudentia (dalam Sudikan, 2013:39), tradisi lisan merupakan berbagai pengetahuan dan adat kebiasaan yang berlangsung secara turun menurun dan disampaikan secara lisan yang mencakup hal-hal yang tidak hanya berupa mite, cerita rakyat, dan legenda, tetapi juga menyimpan sistem kekerabatan yang lebih lengkap, seperti sejarah, hukum adat, dan pengobatan. Merujuk pada pendapat tersebut, berbagai wilayah di Indonesia sepertinya mempunyai tradisi lisan tersendiri, tergantung pada etnis atau kelompok dengan budayanya masing-masing.

Dalam kehidupan masyarakat di Bintan, sastra lisan merupakan suatu tradisi yang paling berkembang di banding sastra tulis. Hal ini didukung oleh kebiasaan berkumpul dan bertutur oleh masyarakatnya. Kebiasaan bercerita menjadi kebisaan yang paling menarik untuk dilakukan dan tentu dengan maksud dan tujuan tertentu. Hal ini serupa dengan kesimpulan yang disampaikan oleh Teew (2003:249) bahwa sastra lisan memang masih berfungsi sebagai sarana komunikasi langsung, tidak harus ditunda dengan kemungkinan tulisan. Apapun jenis sastranya, baik lisan maupun tulisan, sesungguhnya juga tidak terlepas dari fungsinya yakni "dulce dan utile", artinya indah dan berguna (dalam Wellek dan Warren, 1989:25). Kebudayaan yang tersebar dan diturunkan secara turun menurun oleh suatu kelompok, baik secara lisan maupun yang disertai dengan gerak isyarat atau alat bantu pengingat dapat pula didefinisikan sebagai folklor (Danandjaja,1991:2). Lebih lengkap 
lagi, Brunvand (dalam Sudikan, 2013:39) mengelompokkan folklor ke dalam beberapa kategori, yakni folklor lisan yang jenisnya murni lisan dan folklor sebagian lisan yang bentuknya merupakan campuran antara unsur lisan dan bukan lisan, seperti kepercayaan rakyat atau yang sering disebut sebagai takhayul.

Hingga saat ini, masyarakat Bintan masih mempercayai beberapa kepercayaan rakyat atau takhayul yang secara turun-temurun memang diyakini memiliki arti dan kebenaran tersendiri, meskipun perkembangannya tidak seluas masa dahulu. Hal ini tidak lain karena pengaruh dari kebudayaan luar dan kehidupan modern yang mulai memasuki berbagai aspek kehidupan masyarakat Melayu Bintan. Masyarakat Bintan sudah terbiasa hidup dan berinteraksi dengan alam sehingga apa pun yang terjadi dengan alam dapat dijadikan sebagai pembelajaran yang baik dalam kehidupan mereka secara pribadi maupun bermasyarakat. Terlebih daerah tersebut sebagian besar terdiri atas wilayah lautan. Masyarakat sudah biasa dengan istilah "lautan sakti rantau bertuah". Dari laut, mereka mempercayai dan mempelajari banyak hal yang kemudian diwariskan secara turun temurun agar dapat dijadikan pembelajaran bagi generasi berikutnya sehingga kesalahankesalahan yang telah terjadi pada masa dahulunya tidak terjadi lagi pada masa yang akan mendatang.

Data-data hasil penelitian tersebut secara lebih lengkap akan dibahas dan dideskripsikan sebagai berikut.

\section{A. Bentuk Kepercayaan Rakyat Masyarakat Melayu Kabupaten Bintan yang Berhubungan dengan Lingkaran Hidup Manusia.}

Data kepercayaan rakyat masyarakat Kabupaten Bintan mengenai lingkaran hidup manusia dikelompokkan berdasarkan kategori yang dikelompokkan oleh Wayland D. Hand (dalam Danandjaya, 1991) yakni: masa lahir, bayi, dan masa kanak-kanak, tubuh manusia dan obat-obatan rakyat, rumah dan pekerjaan rumah tangga, mata pencaharian dan hubungan sosial, perjalanan dan perhubungan, cinta dan menikah, kematian dan adat pemakaman.

a) Masa lahir, bayi, dan masa kanak-kanak.

Hingga saat ini, terdapat beberapa pantang larang yang masih sangat familiar bagi masyarakat Bintan mengenai kehamilan, yaitu:

1. Ibu hamil dan suaminya tidak boleh menganiaya hewan, dipercaya anaknya akan terlahir cacat.

2. Seorang suami dan ibu hamil tidak boleh memancing selama si istri mengandung karena dipercaya anaknya akan lahir sumbing.

3. Larangan Ibu hamil keluar magrib, dipercaya akan diikuti hantu. Ada kepercayaan dibeberapa wilayah lain, apabila dilanggar maka akan kehilangan janinnya.

4. Larangan bagi ibu hamil mencela orang lain, dipercaya bayinya akan terlahir berperangai buruk seperti orang yang ia cela.

5. Ibu hamil dan Ibu yang melahirkan belum sampai 40 hari tidak boleh turun ke laut, dipercaya akan dilarikan hantu.

6. Masih mempercayai gunting, paku, bawang sebagai penangkal pengaruh rohroh jahat.

7. Larangan melilitkan handuk maupun benda lainnya ke leher diyakini anak yang lahir terlilit tali pusar.

8. Larangan ibu hamil duduk di pintu, diyakini akan susah melahirkan.

9. Larangan Ibu hamil makan buah kembar, dipercaya anak lahir kembar.

10. Larangan ibu hamil keluar pada saat gerhana bulan, dipercaya bayinya akan terlahir hitam.

Selanjutnya, pada masa bayi, ada beberapa kepercayaan rakyat yang masih dipercayai oleh masyarakat Melayu Bintan

1. Bayi harus digendong menjelang magrib, dan dilarang keluar rumah pada saat adzan magrib, agar tidak diganggu hantu.

2. Larangan bayi dibawa keluar pada tengah hari atau pada saat matahari di atas kepala, 
nanti akan disapa oleh makhlus halus dan menyebabkan anak sakit.

3. Plasenta anak bayi harus dibersihkan dan dikubur dalam-dalam di tanah yang bersih, kalau tidak, nanti sang anak akan sering sakit-sakitan atau akan diikuti terus oleh roh jahat atau binatang buas.

Hal ini, secara ilmuan memang tidak dapat dilogikakan, akan tetapi begitulah kenyataannya folklor. Seperti yang dikatakan oleh Danandjaya (1991:4) bahwa salah satu ciri folklor ialah bersifat pralogis, yakni memiliki logika sendiri yang tidak sesuai dengan logika umum. Sama halnya seperti kepercayaan rakyat seputar masa kanak-kanak.

4. Larangan anak tidak boleh bersiul di malam hari, nanti ular masuk rumah.

5. Anak-anak tidak boleh membuka payung di dalam rumah, nanti disambar petir.

6. Anak-anak tidak boleh memotong kuku malam hari, nanti orang tuanya meninggal.

7. Anak-anak tidak boleh duduk di pintu, nanti rezeki jauh.

8. Anak-anak tidak boleh duduk di atas bantal, nanti bisul.

9. Anak-anak tidak boleh tidak menghabiskan makanan, nanti makanannya menangis".

10.Anak-anak tidak boleh berbaring dengan posisi kaki lebih tinggi dari pada kepala, nanti orang tua meninggal.

11.Anak-anak tidak boleh makan tebu malammalam, nanti ibu meninggal.

Semua itu merupakan bentuk kepercayaan masyarakat yang diyakini kebenarannya secara universal di Bintan, meskipun hal-hal tersebut berada di luar logika secara umum.

b) Tubuh manusia dan obat-obatan rakyat

Bagi masyarakat Melayu di Kabupaten

Bintan, bagian dari anggota tubuh yang harus dijaga adalah kepala karena bagian tersebut dianggap sudah difitrahkan oleh ayahnya pada saat lahiran. Kemudian juga terdapat pantang larang yang menyatakan larangan menyentuh kepala dengan cara yang kasar, nanti bisa bodoh. Akibatnya, masyarakat Melayu sangat tidak membenarkan adanya tindakan yang dapat melecehkan kepala, baik oleh orang dewasa ke anak-anak, apalagi sebaliknya.
Kemudian, mengenai obat-obatan, dalam kehidupan masyarakat Melayu Kabupaten Bintan saat ini masih ada beberapa tanaman herbal yang dipergunakan untuk pengobatan tradisonal, yaitu

1. Meminum rebusan daun sirih dipercaya dapat memberikan efek baik pada kesehatan badan, menghilangkan bau badan, dan mengobati batuk.

2. Meminum rebusan daun kumis kucing dapat menurunkan panas dalam.

3. Meminum perasan air cincau dapat menurunkan panas dalam.

4. Kunyit bisa berguna untuk menurunkan demam anak apabila dioleskan ke kening dan dibacakan shalawat.

5. Air rebusan jahe juga dapat berfungsi untuk meningkatkan stamina tubuh serta menghangatkan badan.

6. tanaman lidah buaya atau aloe vera biasanya dimanfaatkan masyarakat untuk menyuburkan rambut.

7. Olesan tumbukan daun singkong untuk pengobatan terhadap luka.

8. Tanaman serai dapat digunakan untuk mengobati orang-orang yang terkena gangguan ilmu hitam.

c) Rumah dan pekerjaan

Mengenai rumah dan pekerjaan rumah, dalam kepercayaan masyarakat Melayu di Kabupaten Bintan, hingga saat ini masih terdapat beberapa hal yang diyakini dan harus digaja dan diperhatikan :

1. Tradisi menggali lubang sebelum dilakukan pembangunan pondasi awal. Pada lubang tersebut ditanamkan sesajian dan dibacakan beberapa mantra dan doa yang dipimpin oleh seseorang yang dipercayai punya kekuatan atau ilmu spiritual.

2. Larangan memasang pintu kamar yang berhadapan karena akan mendatangkan sial dan malapetaka bagi seluruh penghuni rumah.

3. Larangan menanam pohon pisang dan ceri di depan rumah karena tanaman tersebut dipercayai sebagai tempat bermukimnya roh halus dan makhluk gaib.

4. Setiap rumah harus memiliki sapu lidi agar terhindar dari roh jahat. 
5. Larangan membuka pintu rumah pada saat magrib agar terhidar dari makhluk halus dan roh jahat.

6. Larangan meninggalkan rumah sampai 40 hari setelah salah seorang penghuni rumah meninggal.

7. Larangan pindah rumah pada hari Selasa karena hari Selasa dianggap sebagai hari sial atau hari yang kurang baik.

Hal ini tentu menjadi suatu kepercayaan yang meskipun terkadang berada di luar logika. Suatu keyakinan atau kepercayaan yang terus tumbuh dan kemudian dianggap sebagai suatu kebenaran, menurut Barthes (dalam Hasanuddin, 2015) tidak dapat dipersalahkan. Hal yang perlu diperhatikan bukanlah mengenai benar atau salahnya suatu kepercayaan masyarakat, melainkan sejauh mana keyakinan itu memberi fungsi terhadap berbagai aspek dalam kehidupan masyarakatnya.

Kemudian dalam hal pekerjaan, bahwa sebagian besar penduduk adalah nelayan, ada kepercayaan rakyat yang masih begitu dijaga oleh masyrakat Bintan, yakni :

1. Tidak boleh memesan ikan kepada nelayan yang akan berangkat ke laut, nanti nelayan tidak dapat ikan.

2. Nelayan yang hendak ke laut, tidak boleh turun dari rumah apabila ada orang yang sedang makan di atas rumah.

Mayoritas mata pencaharian masyarakat Melayu di Bintan adalah nelayan. Hal ini tentu dipengaruhi oleh luasnya wilayah laut daripada wilayah daratan. Untuk menjadi petani merupakan hal sulit bagi sebagian besar penduduk di Bintan, sebab tidak banyak tanah yang bisa diklaim menjadi hak milik, di samping itu kondisi tanah yang kurang subur. Sebagian besar wilayah daratan di Bintan merupakan kawasan pertambangan bauksit. Para nelayan umumnya mampu membuktikan bahwa kehidupan lebih sejahtera bagi mereka yang berani melaut. Hal tersebut juga menjadikan pandangan masyarakat Melayu bahwa profesi petani dan nelayan lebih baik daripada berdagang. d) Perjalanan dan perhubungan

Selanjutnya mengenai perjalanan dan perhubungan, dalam kehidupan masyarakat Melayu Kabupaten Bintan terdapat beberapa pantang larang yang dipercayai memiliki dampak apabila ada yang melanggarnya,

1. Seseorang hanya boleh melakukan perjalanan apabila mendapat restu atau izin dari orang tua, sebab bila tidak maka dipercaya akan terjadi sesuatu hal yang tidak diinginkan.

2. Larangan berjalan pada saat magrib, sebab pada saat itu, roh-roh halus juga sedang melakukan perjalanan.

3. Larangan melakukan perjalanan apabila sudah tiga kali kembali ke rumah oleh karena ada yang tertinggal dan sebagainya. Hal ini dikhawatirkan sebagai pertanda bahwa akan terjadi sesuatu yang tidak diinginkan.

4. Larangan melakukan perjalanan apabila telah menabrak kucing. Kucing yang ditabrak harus dikuburkan.

5. Larangan menoleh ke belakang ketika melakukan perjalanan laut, dipercaya akan digoda hantu.

6. Kepercayaan mendapatkan banyak rezeki, ketika melaut melihat pelangi.

e) Pernikahan dan adat

Selanjutnya mengenai pernikahan. Pernikahan yang dianjurkan dalam kehidupan masyarakat Melayu di Bintan adalah pernikahan sesuku. Masyarakat Melayu Bintan tidak melarang apabila ada diantara keluarganya yang menikah sesama suku, sebab bagi mereka akan lebih baik apabila anggota mereka menikah dengan orang-orang yang masih mereka kenal keluarganya. Hal ini tentu wajar dengan pola pikir masyarakat pada umumnya bahwa untuk menjadikan orang lain menjadi bagian dari anggota keluarga yang baru, tentu harus tahu bibit, bebet, dan bobotnya. Maka tidak sulit untuk mengetahui hal itu apabila orang tersebut adalah orangorang terdekat dari mereka. Bagi masyarakat Melayu, pernikahan yang dilarang ialah pernikahan yang setali darah dan sepupu dekat. 
Sebagian besar masyarakat Melayu beragama Islam, sehingga prosesi atau adat pemakaman masyarakat Melayu Bintan mengikuti sariat ajaran agama Islam. Namun, hingga saat ini masih terdapat beberapa kepercayaan yang dijaga oleh masyarakat pada saat si mayat belum dikuburkan, yakni : Mayat yang terbujur di tengah rumah harus sangat dilindungi dari kucing dan lalat. Jangan sampai kucing melangkahi mayat, nanti seisi rumah akan ditimpa sial, atau tidak baik bagi si mayat, dan bahkan bisa membuat si mayat hidup kembali." Hal ini tentu bukan menjadi sesuatu yang diharapkan oleh keluarga dan masyarakat sekitar.

Binatang lalat juga dipercayai sebagai binatang utusan roh halus. Binatang tersebut bisa mengganggu roh yang akan berpulang pada ilahi.

\section{B. Bentuk Kepercayaan Rakyat Masyarakat Melayu Kabupaten Bintan Mengenai Alam Gaib.}

Data mengenai kepercayaan rakyat mengenai alam gaib merupakan bagian paling besar dari kepercayaan rakyat. Laut diyakini punya kekuatan gaib yang mampu menguasai alam sekitar manusia, termasuk alam pikiran, dan tingkah laku manusia. Laut juga dipercayai sebagai tempat tinggal atau bermukimnya rohroh halus.

1. Larangan Seorang ibu hamil, bayi, maupun ibu yang baru saja melahirkan melakulan perjalanan laut. Ibu hamil atau yang sedang menyusui dianggap sebagai manusia yang dapat membangkitkan selera atau nafsu para roh karena dianggap memiliki bau yang harum bagi para penghuni laut tersebut.

2. Calon mempelai tidak boleh turun ke laut sebelum hari pernikahan, dipercaya bahwa calon mempelai juga memiliki bau yang khas yang disukai oleh para roh halus.

Selain wilayah laut, masyarakat Melayu Bintan juga percaya dengan adanya kekuatan alam lain dan penguasanya yang dikenal dengan sebutan "orang Bunian". Jika ada warga yang hilang, itu tandanya disembunyikan.

oleh orang bunian atau mahluk halus". Maka untuk menemukan korban yang hilang, biasanya masyarakat akan berbondongbondong berarak sambil memukul kentongan yang didampingi oleh dukun yang mampu mengetahui alam gaib tersebut. Biasanya beberapa benda dan sesajian turut menyempurnakan ritual, sampai akhirnya si korban ditemukan kembali oleh masyarakat.

\section{Bentuk Kepercayaan Rakyat Masyarakat Melayu di Kabupaten Bintan Mengenai Terciptanya Alam Semesta dan Dunia.}

Dalam kehidupan masyarakat Melayu di Kabupaten Bintan, ada beberapa fenomena yang diyakini dapat memberi pertanda pada masyarakatnya, yakni :

1. Apabila terjadi hujan panas, itu pertanda bahwa ada orang yang meninggal dengan cara yang tidak wajar.

2. Jika ada kupu-kupu yang masuk rumah, ini pertanda bahwa ada tamu yang akan berkunjung ke rumah tersebut.

3. Kepercayaan mayarakat Bintan pada masa dahulu bahwa pelangi itu pertanda adanya bidadari yang turun untuk mandi ke pusat mata air.

4. Bunyi burung gagak yang terbang mengitari rumah pertanda bahwa akan ada orang yang meninggal. Burung gagak dianggap sebagai penyampai kabar buruk.

Hingga saat ini, kepercayaan rakyat tersebut masih menjadi suatu cerita yang turuntemurun dan masih memberikan warna tersendiri dalam perkembangan sastra rakyat di daerah Bintan.

\section{Fungsi Kepercayaan Rakyat Masyarakat Melayu Kabupaten Bintan.}

Selanjutnya, dilihat dari segi fungsinya, folklore memiliki 4 fungsi, yaitu:(1) sebagai alat pencermin angan-angan suatu kolektif; (2) sebagai alat pengesahan pranata dan lembaga kebudayaan; (3) sebagai alat pendidikan anak; dan (4) sebagai alat pemaksa dan pengawas agar norma masyarakat dipatuhi (James Danandjaja, hal. 19).

a) Fungsi Kepercayaan atau Pantang Larang Masyarakat Melayu Kabupaten Bintan 
JURNAL KIPRAH, Desember 2018; V1(2): 8-16

e-ISSN: 2580-6947

p-ISSN: 2354-7278

\section{Sebagai Alat Pencermin Angan-angan Suatu Kolektif \\ Pantang larang maupun kepercayaan} masyarakat Bintan memiliki nilai-nilai agama, budaya, mencerminkan kesantunan. Selain itu, kepercayaan masyarakat juga menumbuhkan harapan masyarakat terhadap pantang larang dan kepercayaan yang dianggap memiliki petanda baik maupun petanda buruk. Seperti yang kita ketahui, petanda baik akan membuat mereka mendengarnya dan menjadi penyemangat untuk melakukan segala sesuatu, sementara apabila pertanda buruk, maka akan menjadi pesan untuk berhati-hati, dan bersiap menghadapi.

Seperti kepercayaan rakyat yang mengatakan "rezeki tidak berpintu. Semakin banyak memberi maka semakin banyak membuka peluang pintu rezeki terhadap si pemberi". Dengan demikian, masyarakat akan terpancing untuk selalu berbuat kebaikan sehingga terwujudlah suatu angan bahwa yang baik akan selalu dibalas dengan kebaikan pula.

\section{Sebagai Alat Pengesahan Pranata dan Lembaga Kebudayaan \\ Pranata atau aturan masyarakat} terbentuk karena adanya adat kebiasaan. Adat kebiasaan tersebut yang mewarisi genarasi ke genarasi secara turun temurun dari nenek moyang mereka hingga ke anak cucu. Pantang larang ataupun kepercayaan tersebut dibenarkan serta menjadi pengesahan pranata dan lembaga kebudayaan yang terdapat dalam kebudayaan tersebut. Pranata atau aturan sosial masyarakat yang terdapat dalam pantang larang maupun melalui kepercayaan masyarakat memang tidak tertulis, namun masyarakat tetap bisa patuh pada pantangan tersebut. Sebab, seperti yang kita ketahui, pantangan dan larangan disampaikan tersebut ialah dari lisan ke lisan atau dari mulut ke mulut.

\section{Sebagai Alat Pendidikan Anak}

Pantang larang dan kepercayaan nenek moyang merupakan suatu yang diwarisi ke anak cucunya. Melalui kebiasaan yang terdapat dalam pantang larang dan kepercayaan ini dapat menjadi suatu alat pendidikan bagi anak karena di dalam pantang larang tersebut banyak sekali aturan-aturan yang berkaitan dengan agama, moral, sopan santun, tata karma maupun berbuat sesuatu hal yang baik. Nilai pendidikan yang diambil ialah sopan santun dan menghormati sesama manusia dengan begitu akan meciptakan kehidupan harmonis baik dilingkungan keluarga maupun lingkungan masyarakat

Hal yang sama terdapat pada larangan "tidak boleh bangun tidur terlalu siang karena rezeki akan dipatok ayam". Kita tahu bahwa bangun siang itu perilaku yang kurang baik. Apabila kita bangun siangpun, tentu kita akan terlambat ke sekolah untuk menimba ilmu maupun untuk bekerja. Nilai pendidikan yang dapat diambil dari pantang larang ini ialah menjaga perilaku sesuai dengan adab dan aturan dalam kehidupan bermasyarakat serta berbuat segala sesuatu sesuai kepatutan.

Selain itu, juga pesan dalam pantang larang untuk menghindari menyinggung orang lain. Nilai pendidikan yang dapat diambil dari pantang larang ini ialah berbuat kebaikan, yaitu keikhlasan memberi kepada orang lain.

Dengan adanya pantang larang dan kepercayaan semacam ini akan membuat anak cucunya mengerti dan memahami apa saja yang harus dihindari dan apa saja aturan-aturan yang harus diikuti. Memang seharusnya, kebudayaan bisa menjadi suatu pendidikan untuk anak-anak memiliki tujuan maupun pedoman yang dapat menuntun mereka ke arah lebih baik.

4. Sebagai Alat Pemaksa dan Pengawas Agar Norma Masyarakat Dipatuhi

Kepercayaan atau pantang larang ini mengandung norma-norma yang tidak tertulis, namun tetap dipatuhi oleh mayarakat. Masyarakat Bintan memang sudah seharusnya patuh pada pantang larang yang diwarisi nenek moyangnya dari turun-temurun. Semua pantang larang yang diwarisi oleh nenek moyang tersebut pastinya berguna demi kebaikan anak cucunya. Pantang larang memang berguna sebagai alat pemaksa dan pengawas norma masyarakat yang harus dipatuhi, jadi memang wajar jika masyarakat merasa takut ketika sampai melanggar pantang larang tersebut. Pantang larang atau kepercayaan dianggap sebagai suatu yang sakral. 
Salah satunya adalah "dilarangan duduk di depan atau di tengah pintu karena akan menyebabkan dirinya susah jodoh". Pantang larang tersebut juga berhubungan dengan adab dan tata krama berperilaku dalam masyarakat. Bahwa duduk di depan pintu akan menghalangi orang masuk ke rumah. Pantang larang ini juga berguna sebagai pemaksa dan pengawas agar norma masyarakat dipatuhi.

Pantang larang "tidak boleh makan sambil berjalan" berhubungan dengan tata krama dan adab perilaku dalam masyarakat karena makan yang baik adalah dengan posisi duduk, bukan dengan posisi berjalan atau bahkan tiduran. Masyarakat Bintan percaya bahwa apa yang ada dalam pantang larang tersebut pastilah berhubungan dengan aturanaturan dan norma dalam masyarakat.

Hal yang sama juga dapat diliihat pada pantang larang yang berbunyi, "jangan mengintip orang mandi karena akan menyebabkan mata bintitan". Bagi mereka yang melihat aurat perempuan atau laki-laki, baik sengaja maupun tidak sengaja, baik secara langsung maupun tidak langsung, maka haram hukumnya dan dikatakan masuk dalam perzinaan. Jadi, mengintip orang mandi merupakan pebuatan zina dan tentunya melanggar norma dan aturan dalam masyarakat. Dengan adanya pantang larang ini, maka dapat juga berfungsi sebagai pemaksa dan pengawas norma-norma masyarakat. Hal tersebut akan membatasi manusia untuk berbuat yang tidak baik dengan cara masyarakat akan merasa takut jika melakukan hal tersebut.

\section{KESIMPULAN}

Tradisi lisan dalam kehidupan masyarakat Melayu di Kabupaten Bintan mencakup beberapa hal yang menyangkut lingkaran hidup manusia, yakni bagaimana proses kelahiran manusia dan hal-hal yang dapat mempengaruhinya, kemudian kepercayaan terhadap alam gaib, dan kepercayaan mengenai terciptanya alam semesta dan dunia. Cerita yang diyakini oleh masyarakat Melayu pada satu kecamatan dengan kecamatan lain di Kabupaten Bintan pada dasarnya memiliki pola serupa, meskipun dengan variasi yang sedikit berbeda-beda. Hampir tidak ada perbedaan persepsi tentang cerita dan pantang larang yang telah lama dipercayai secara turun-temurun oleh masyarakat Bintan. Kepercayaan rakyat masyarakat Melayu Bintan juga merupakan bagian dari kebudayaan yang memiliki berbagai fungsi, sehingga dapat mengatur dan mengarahkan kehidupan masyarakatnya agar menjadi lebih baik.

Berdasarkan temuan ini, disarankan agar seluruh masyarakat dan lembaga-lembaga swasta agar mampu mendukung dan mengembangkan budaya lokal sebagai pembentuk karakter bangsa. Selanjutnya juga disarankan kepada pemerintah daerah untuk ambil andil dalam pemertahanan kebudayaan daerah. Pemerintah perlu mengupayakan penggalian dan perumusan rancangan agar tradisi lisan setempat tidak punah dan tetap bertahan dalam kehidupan modern. Perguruan tinggi juga diharapkan dapat memacu para peneliti untuk aktif mendokumentasikan, menganalisis, selanjutnya ikut merumuskan upaya pelestarian kebudayaan setempat.

\section{UCAPAN TERIMA KASIH}

Ucapan terima kasih disampaikan kepada Direktorat Riset dan Pengabdian Masyarakat, Direktorat Jenderal Penguatan Riset dan Pengembangan, Kemenristekdikti yang telah memberikan dana penelitian dosen pemula, serta pihak LP3M Universitas Maritim Raja Ali Haji dan semua pihak yang telah membantu terlaksananya penelitian ini.

\section{DAFTAR PUSTAKA}

Danandjaja, James. 1991. Folklore Indonesia: Ilmu Gosip, Dongeng, Dan Lain-lain. Jakarta : Grafiti Press.

Hasanuddin. 2015. Jurnal Keilmuan Bahasa, Sastra, dan Pengajarannya.Vol.1, 198-204. http://www.google.co.id/search?q=jurnal+hasa nuddin+kepercayaan+rakyat \&aqs $=$ chrome..69i 57.19375j0j7\&client=ms-android-asus-

tpin\&sourceid=chrome-mobile $\& \mathrm{ie}=\mathrm{UTF}-8$

Sudikan, Setya Yuwana. 2013. Kearifan Budaya Lokal. Jawa Timur: Damar Ilmu.

Sugiyono. 2005. Memahami Penelitian Kualitatif. Bandung: Alfabeta

Teeuw, A. 2003. Sastra dan Ilmu Sastra: Pengantar Teori Sastra. Jakarta: Pustaka Jaya.

Wellek, Rene dan Austin Warren. 1995. Teori Kesusastraan (Edisi Terjemahan). Jakarta: Gramedia. 
JURNAL KIPRAH, Desember 2018; V1(2): 8-16

e-ISSN: 2580-6947

p-ISSN: 2354-7278 